\title{
Neuropathic pain characteristics in patients from Curitiba (Brazil) with spinal cord injury
}

\author{
Janaína Vall ${ }^{1,3}$, Carlos Mauricio de Castro Costa ${ }^{2,3}$, \\ Terezinha de Jesus Teixeira Santos 3 , Samuel Bovy de Castro Costa ${ }^{3}$
}

\begin{abstract}
This was a descriptive cross-sectional study on patients with spinal cord injuries living in Curitiba, Paraná, Brazil. The aim was to evaluate the pain characteristics among such patients seen at referral care centers for spinal cord injury patients in Curitiba. A total of 109 adults with spinal cord injury in this city were evaluated regarding the presence of pain, especially neuropathic pain. Neuropathic pain was evaluated using the DN4 questionnaire, a universal instrument that has been translated and validated for Portuguese. A visual analog scale (VAS) was used to evaluate the intensity of pain. The prevalence of pain among these 109 patients was $31.2 \%$ (34 patients). The nociceptive pain presented was classified as musculoskeletal pain (nine patients), visceral pain (four patients) and mixed pain (one patient), thus totaling 14 patients (12.8\%). Another 20 patients (18.3\%) showed symptoms of neuropathic pain and fulfilled the criteria for neuropathic pain with scores greater than 4 out 10 in the DN4 questionnaire. Regarding the characteristics of the patients with neuropathic pain, most of them were male, younger than 40 years of age and paraplegic with incomplete lesions. They had become injured from 1 to more than 5 years earlier. The predominant etiology was gunshot wounds, and the intensity of their pain was high, with VAS scores greater than 5 . This study partially corroborates other studies conducted on this subject. Studies of this type are important for understanding the profile of these patients, for the purpose of designing strategies for their rehabilitation, with a focus on the appropriate treatment and management of pain.
\end{abstract}

Key words: neuropathic pain, spinal cord injury, DN4 questionnaire.

\section{Dor neuropática em pessoas com lesão medular residentes em Curitiba (Brasil)}

\section{RESUMO}

Estudo transversal descritivo em pacientes com lesão medular que residem em Curitiba, Paraná, Brasil. O objetivo foi avaliar as características da dor em pacientes com lesão medular acompanhados em Centros de Reabilitação de referência na cidade. Os sujeitos envolvidos na pesquisa foram 109 pacientes adultos com lesão medular. Foi avaliada a presença de dor, principalmente dor neuropática, mediante aplicação do Questionário DN4, um instrumento universal traduzido e validado para o português. A Escala Visual Analógica (EVA) também foi usada para avaliar a intensidade da dor. A prevalência de dor nos 109 pacientes avaliados foi de 31,2\%, ou seja, 34 pacientes. Destes, nove apresentaram dor nociceptiva classificada como músculo-esquelética, quatro dor visceral e um paciente apresentou dor mista, totalizando 14 pacientes (12,8\%). Além disso, 20 pacientes (18,3\%) apresentaram dor neuropática, cumprindo os critérios para este tipo de dor com uma contagem superior a 4/10 para o DN4. Sobre as características dos pacientes com dor neuropática, a maioria era do sexo masculino, abaixo de 40 anos, paraplégico com lesão incompleta e tempo de evolução entre um e cinco anos de lesão. A etiologia

\section{Correspondence \\ Janaína Vall \\ Rua José Nicco 105 \\ 81200-300 Curitiba PR - Brasil \\ E-mail: janaina_vall@yahoo.com.br}

Received 19 April 2010

Received in final form 15 June 2010

Accepted 22 June 2010
${ }^{1} \mathrm{PhD}$ in Medical Sciences, MSc in Nursing, Federal University of Ceará. Professor of the UniBrasil. Coordinator of the "Liga Sem Dor"; ${ }^{2}$ Full Professor of Physiology/Neurology, Federal University of Ceará; ${ }^{3}$ Researcher in the Experimental Neurology and Neurophysiology Laboratory, Department of Physiology and Pharmacology, Federal University of Ceará. 
predominante foi perfuração por arma de fogo e a intensidade da dor era severa, com EVA superior a cinco. Este estudo confirma parcialmente outros estudos publicados sobre o tema. Pesquisas deste tipo são importantes para entender o perfil destes pacientes com a finalidade de estabelecer estratégias para uma reabilitação com foco no tratamento e manejo adequado da dor.

Palavras-chave: dor neuropática, lesão medular, questionário DN4.

Spinal cord injury not only causes impairment of motor function and loss of or decreased feeling, but also can cause many complications. One of the greatest and most debilitating of these complications is chronic pain, characterized mainly by neuropathic pain ${ }^{1-4}$. This is a spontaneous pain that occurs mainly in situations of sensory abnormality, caused by a primary lesion or disease of the peripheral or central nervous system ${ }^{1,5}$. Differing from nociceptive pain, neuropathic pain is more difficult to treat $t^{5,6}$.

Thus, appropriate handling of neuropathic pain following spinal cord injury is very important and necessary, since these patients suffer from a common problem and because this pain has a greater impact on everyday activities $^{3,6}$, besides being a major factor in depression and unemployment ${ }^{3}$. Many people with chronic pain say that paralysis does not impede them from working and having an active social life, but that the pain they feel does. Chronic pain is the complication that is most related to lower scores in evaluations of quality of life $\mathrm{e}^{7-9}$.

Chronic pain is thus a concern that very many patients with spinal cord injury have, and it directly affects daily activities and hinders the rehabilitation process. Studying this specific type of pain is therefore of great importance.

The objective of this study was to determine the prevalence, intensity and patient characteristics of pain, and especially neuropathic pain, among individuals with spinal cord injuries in the city of Curitiba, Brazil.

\section{METHOD}

A descriptive cross-sectional study was conducted on 109 patients with spinal cord injuries (both traumatic and nontraumatic) who were recruited consecutively and followed up at different referral centers caring for such patients in the city of Curitiba, Paraná, Brazil, during 2008. The inclusion criteria were that the subjects should be patients with spinal cord injuries of traumatic or nontraumatic origin who complained of pain after the onset of the condition.

Gender, age (years), marital status, schooling and occupation, etiology of and time with the injury (years), neurological status and type of lesion (complete or incomplete, according to the ASIA Impairment Scale, AIS) ${ }^{10}$ were the independent variables analyzed in this study.

The DN4 questionnaire, which was originally in
Table 1. Demographic and clinical characteristics of the patients with spinal cord injury.

\begin{tabular}{|c|c|c|}
\hline \multirow{2}{*}{ Category } & \multicolumn{2}{|c|}{ Total } \\
\hline & $\mathrm{N}$ & $\%$ \\
\hline $\begin{array}{l}\text { Gender } \\
\text { Male } \\
\text { Female }\end{array}$ & $\begin{array}{l}92 \\
17\end{array}$ & $\begin{array}{l}(84.4) \\
(15.6)\end{array}$ \\
\hline $\begin{array}{l}\text { Age } \\
\qquad \begin{array}{l}<21 \\
21 \text { to } 40 \\
41 \text { to } 50 \\
\geq 51\end{array}\end{array}$ & $\begin{array}{c}9 \\
73 \\
14 \\
13\end{array}$ & $\begin{array}{l}(8.3) \\
(67.0) \\
(12.8) \\
(11.9)\end{array}$ \\
\hline $\begin{array}{ll}\text { Mean } & 32.88 \\
\text { Standard deviation } & 11.72 \\
\text { Median } & 30\end{array}$ & & \\
\hline $\begin{array}{l}\text { Marital status } \\
\text { Single } \\
\text { Married } \\
\text { Other }\end{array}$ & $\begin{array}{l}44 \\
50 \\
15\end{array}$ & $\begin{array}{l}(40.4) \\
(45.9) \\
(13.8)\end{array}$ \\
\hline $\begin{array}{l}\text { Occupation } \\
\text { Not working } \\
\text { Working } \\
\text { Retired } \\
\text { Others }\end{array}$ & $\begin{array}{l}28 \\
22 \\
35 \\
24\end{array}$ & $\begin{array}{l}(25.7) \\
(20.2) \\
(32.1) \\
(22.0)\end{array}$ \\
\hline $\begin{array}{l}\text { Schooling } \\
\text { Illiterate } \\
\text { Basic education } \\
\text { Middle-level education } \\
\text { Higher education }\end{array}$ & $\begin{array}{l}11 \\
54 \\
38 \\
6\end{array}$ & $\begin{array}{c}(10.1) \\
(49.5) \\
(34.9) \\
(5.5)\end{array}$ \\
\hline $\begin{array}{l}\text { Etiology } \\
\text { Gunshot wound } \\
\text { Fall from height } \\
\text { Knife wound } \\
\text { Traffic accident } \\
\text { Nontraumatic }\end{array}$ & $\begin{array}{c}49 \\
12 \\
5 \\
36 \\
7\end{array}$ & $\begin{array}{c}(45.0) \\
(11.0) \\
(4.6) \\
(33.0) \\
(6.4)\end{array}$ \\
\hline $\begin{array}{l}\text { Neurological status } \\
\text { Paraplegic } \\
\text { Tetraplegic }\end{array}$ & $\begin{array}{l}79 \\
30\end{array}$ & $\begin{array}{l}(72.5) \\
(27.5)\end{array}$ \\
\hline $\begin{array}{l}\text { Type of lesion } \\
\text { Incomplete } \\
\text { Complete }\end{array}$ & $\begin{array}{l}43 \\
66\end{array}$ & $\begin{array}{l}(39.4) \\
(60.6)\end{array}$ \\
\hline $\begin{array}{l}\text { Time with lesion } \\
\quad<1 \text { year } \\
1 \text { to } 5 \text { years } \\
>5 \text { years }\end{array}$ & $\begin{array}{l}17 \\
55 \\
37\end{array}$ & $\begin{array}{l}(15.6) \\
(50.5) \\
(33.9)\end{array}$ \\
\hline $\begin{array}{l}\text { Neuropathic pain } \\
\text { No } \\
\text { Yes }\end{array}$ & $\begin{array}{l}89 \\
20\end{array}$ & $\begin{array}{l}(81.7) \\
(18.3)\end{array}$ \\
\hline $\begin{array}{l}\text { Pain location in relation } \\
\text { to lesion level } \\
\text { At level } \\
\text { Below level } \\
\text { Above level }\end{array}$ & $\begin{array}{c}2 \\
18 \\
0\end{array}$ & $\begin{array}{c}(10.0) \\
(90.0) \\
(0.0)\end{array}$ \\
\hline
\end{tabular}


Table 2. Diagnostic characteristics of neuropathic pain in 20 spinal cord injury patients, according to the DN4 questionnaire criteria.

\begin{tabular}{|c|c|c|}
\hline $\begin{array}{l}\text { Patient } \\
\text { number }\end{array}$ & Descriptors & Score \\
\hline 1 & $\begin{array}{l}\text { Burning, tingling, hypoesthesia to touch } \\
\text { and prick }\end{array}$ & $4 / 10$ \\
\hline 2 & $\begin{array}{l}\text { Burning, numbness, hypoesthesia to } \\
\text { touch and prick }\end{array}$ & $4 / 10$ \\
\hline 3 & $\begin{array}{l}\text { Electric shock, pins and needles, hypoes- } \\
\text { thesia to touch and prick }\end{array}$ & $4 / 10$ \\
\hline 4 & $\begin{array}{l}\text { Burning, tingling, hypoesthesia to touch } \\
\text { and prick }\end{array}$ & $4 / 10$ \\
\hline 5 & $\begin{array}{l}\text { Burning, numbness, hypoesthesia to } \\
\text { touch and prick }\end{array}$ & $4 / 10$ \\
\hline 6 & $\begin{array}{l}\text { Burning, tingling, hypoesthesia to touch } \\
\text { and prick }\end{array}$ & $4 / 10$ \\
\hline 7 & $\begin{array}{l}\text { Electric shock, pins and needles, hypoes- } \\
\text { thesia to touch and prick }\end{array}$ & $4 / 10$ \\
\hline 8 & $\begin{array}{l}\text { Electric shock, tingling, hypoesthesia to } \\
\text { touch and prick }\end{array}$ & $4 / 10$ \\
\hline 9 & $\begin{array}{l}\text { Burning, tingling, hypoesthesia to touch } \\
\text { and prick }\end{array}$ & $4 / 10$ \\
\hline 10 & $\begin{array}{l}\text { Burning, numbness, hypoesthesia to } \\
\text { touch and prick }\end{array}$ & $4 / 10$ \\
\hline 11 & $\begin{array}{l}\text { Burning, tingling, hypoesthesia to touch } \\
\text { and prick }\end{array}$ & $4 / 10$ \\
\hline 12 & $\begin{array}{l}\text { Burning, tingling, hypoesthesia to touch } \\
\text { and prick }\end{array}$ & $4 / 10$ \\
\hline 13 & $\begin{array}{l}\text { Electric shock, pins and needles, hypoes- } \\
\text { thesia to touch and prick }\end{array}$ & $4 / 10$ \\
\hline 14 & $\begin{array}{l}\text { Burning, tingling, hypoesthesia to touch } \\
\text { and prick }\end{array}$ & $4 / 10$ \\
\hline 15 & $\begin{array}{l}\text { Burning, tingling, hypoesthesia to touch } \\
\text { and prick }\end{array}$ & $4 / 10$ \\
\hline 16 & $\begin{array}{l}\text { Electric shock, tingling, hypoesthesia to } \\
\text { touch and prick }\end{array}$ & $4 / 10$ \\
\hline 17 & $\begin{array}{l}\text { Burning, tingling, hypoesthesia to touch } \\
\text { and prick }\end{array}$ & $4 / 10$ \\
\hline 18 & $\begin{array}{l}\text { Burning, tingling, hypoesthesia to touch } \\
\text { and prick }\end{array}$ & $4 / 10$ \\
\hline 19 & $\begin{array}{l}\text { Electric shock, pins and needles, hypoes- } \\
\text { thesia to touch and prick }\end{array}$ & $4 / 10$ \\
\hline 20 & $\begin{array}{l}\text { Burning, tingling, hypoesthesia to touch } \\
\text { and prick }\end{array}$ & $4 / 10$ \\
\hline
\end{tabular}

French, was duly translated and validated for Portuguese, and was used to identify non-neuropathic and neuropathic pain patients. It consists of 10 items subdivided into two parts: sensory descriptors (seven items) and signs relating to the sensory examination (three items) ${ }^{11-13}$. The presence of neuropathic pain was taken to be the depen-
Table 3. Characteristics of the patients with spinal cord injury with symptoms of neuropathic pain.

\begin{tabular}{|c|c|c|c|}
\hline \multirow{2}{*}{ Characteristics } & & \multicolumn{2}{|c|}{ Neuropathic pain } \\
\hline & & Total & $\%$ \\
\hline \multirow[t]{2}{*}{ Gender } & Male & 15 & 75 \\
\hline & Female & 5 & 25 \\
\hline \multirow[t]{2}{*}{ Age } & $<40$ & 15 & 75 \\
\hline & $>41$ & 5 & 25 \\
\hline \multirow[t]{3}{*}{ Marital status } & Single & 8 & 40 \\
\hline & Married & 9 & 45 \\
\hline & Other & 3 & 15 \\
\hline \multirow[t]{4}{*}{ Occupation } & Not working & 4 & 20 \\
\hline & Working & 4 & 20 \\
\hline & Retired & 8 & 40 \\
\hline & Others & 4 & 20 \\
\hline \multirow[t]{4}{*}{ Schooling } & Illiterate & 0 & 0 \\
\hline & Basic education & 11 & 55 \\
\hline & Middle-level education & 8 & 40 \\
\hline & Higher education & 1 & 5 \\
\hline \multirow[t]{3}{*}{ Etiology } & Gunshot wound & 11 & 55 \\
\hline & Other wounds & 3 & 15 \\
\hline & Traffic accidents & 6 & 30 \\
\hline \multirow{2}{*}{$\begin{array}{l}\text { Neurological } \\
\text { status }\end{array}$} & Paraplegic & 14 & 70 \\
\hline & Tetraplegic & 6 & 30 \\
\hline \multirow[t]{2}{*}{ Type of lesion } & Incomplete & 16 & 80 \\
\hline & Complete & 4 & 20 \\
\hline \multirow[t]{3}{*}{ Time with lesion } & $<1$ year & 3 & 15 \\
\hline & 1 to 5 years & 12 & 60 \\
\hline & $>5$ years & 5 & 25 \\
\hline \multicolumn{2}{|l|}{ Total } & 20 & 100 \\
\hline
\end{tabular}

dent variable and needed to reach a score of at least 4 out 10 , while non-neuropathic pain presented scores of less than 4 out 10.

The intensity of the pain, in general, was evaluated using a visual analog scale (VAS) of $10 \mathrm{~cm}$ in length that was graduated from " 0 " to "10," where "0" represented no pain and " 10 " the most unbearable pain ${ }^{14}$. For this study, the results were grouped in the following manner: intensity $\leq 5$ (weak to moderate pain) or $>5$ (strong to intense pain).

The study was approved by the Ethics Committee of the State Department of Health, in Curitiba, and also followed the guidelines and laws of Brazil ${ }^{15}$. The patients signed a consent statement.

\section{RESULTS}

The demographic and clinical characteristics of the patients with spinal cord injury are outlined in Table 1. These patients were mostly males and their mean age was 32.8 years. Their marital status and occupations were similar and their schooling level mostly ranged from illiterate to moderate. Among the etiologies, gunshot wounds and traffic accidents were the most frequent causes. Most of 
Table 4. Intensity of neuropathic pain, correlated with the demographic and clinical variables studied.

\begin{tabular}{|c|c|c|c|c|c|c|c|}
\hline \multirow[b]{3}{*}{ Characteristics } & & \multicolumn{4}{|c|}{ Visual analog scale } & \multirow[b]{3}{*}{ Total } & \multirow[b]{3}{*}{$\%$} \\
\hline & & \multicolumn{2}{|c|}{$<5$} & \multicolumn{2}{|c|}{$>5$} & & \\
\hline & & Total & $\%$ & Total & $\%$ & & \\
\hline \multirow[t]{2}{*}{ Gender } & Male & 2 & 50 & 13 & 81.3 & 15 & 75 \\
\hline & Female & 2 & 50 & 3 & 18.7 & 5 & 25 \\
\hline \multirow[t]{2}{*}{ Age } & $<40$ years & 3 & 75 & 12 & 75 & 15 & 75 \\
\hline & 41 to 50 years & 1 & 25 & 4 & 25 & 5 & 25 \\
\hline \multirow[t]{3}{*}{ Marital status } & Single & 2 & 50 & 6 & 37.5 & 8 & 40 \\
\hline & Married & 2 & 50 & 7 & 43.8 & 9 & 45 \\
\hline & Other & - & - & 3 & 18.7 & 3 & 15 \\
\hline \multirow[t]{4}{*}{ Occupation } & Not working & - & - & 4 & 25 & 4 & 20 \\
\hline & Working & 2 & 50 & 2 & 12.5 & 4 & 20 \\
\hline & Retired & 1 & 25 & 7 & 43.8 & 8 & 40 \\
\hline & Others & 1 & 25 & 3 & 18.7 & 4 & 20 \\
\hline \multirow[t]{3}{*}{ Schooling } & Basic education & 1 & 25 & 10 & 62.5 & 11 & 55 \\
\hline & Middle-level education & 3 & 75 & 5 & 31.2 & 8 & 40 \\
\hline & Higher education & - & - & 1 & 6.3 & 1 & 5 \\
\hline \multirow[t]{3}{*}{ Etiology } & Gunshot wound & 2 & 50 & 9 & 56.3 & 11 & 55 \\
\hline & Others & 1 & 25 & 2 & 12.5 & 3 & 15 \\
\hline & Traffic accident & 1 & 25 & 5 & 31.2 & 6 & 30 \\
\hline \multirow[t]{2}{*}{ Neurological status } & Paraplegic & 3 & 75 & 11 & 68.8 & 14 & 70 \\
\hline & Tetraplegic & 1 & 25 & 5 & 31.2 & 6 & 30 \\
\hline \multirow[t]{2}{*}{ Type of lesion } & Incomplete & 2 & 50 & 14 & 87.5 & 16 & 80 \\
\hline & Complete & 2 & 50 & 2 & 12.5 & 4 & 20 \\
\hline \multirow[t]{3}{*}{ Time with lesion } & $<1$ year & 1 & 25 & 2 & 12.5 & 3 & 15 \\
\hline & 1 to 5 years & 1 & 25 & 11 & 68.8 & 12 & 60 \\
\hline & $>5$ years & 2 & 50 & 3 & 18.7 & 5 & 25 \\
\hline Total & & 4 & 100 & 16 & 100 & 20 & 100 \\
\hline
\end{tabular}

the patients were paraplegic, with complete lesions, and most of them had become injured from one to more than five years earlier (Table 1).

Pain was present in 34 (31.2\%) of the 109 patients evaluated. Among these 34 patients, 14 were classified as having nociceptive pain such as musculoskeletal pain (nine patients), visceral pain (four patients) and mixed pain (one patient). Neuropathic pain was diagnosed in accordance with the DN4 questionnaire in 20 patients (18.3\%) with symptoms suggestive of this, with a score of 4 out 10 in the DN4 questionnaire (Table 2). Among these 20 patients, 18 showed below-level pain, two of them had at-level pain and none had above-level pain.

Table 3 shows the correlation between neuropathic pain and the variables studied. The individuals mostly affected were male, younger than 40 years, single or married, retired, with basic education and paraplegic with incomplete lesion. Most of them had gunshot wounds as the etiology and had become injured from 1 to more than 5 years earlier.

The individuals with these characteristics were the ones who suffered most with the pain, with scores higher than 5 on the VAS, thus showing the pain to be strong to intense (Table 4).

\section{DISCUSSION}

The prevalence of pain secondary to traumatic and nontraumatic spinal cord injury in this study (31.2\%) was not as high as shown by other investigators, possibly due to our small number of patients. Wollaars et al. ${ }^{9}$ evaluated more than 250 patients and found that the prevalence of pain after spinal cord injury was $77 \%$. Finnerup et al. found that $67 \%$ of the individuals with spinal cord injury presented chronic pain ${ }^{16}$. Ravenscroft et al. also showed that the prevalence of pain after spinal cord injury was $79 \%{ }^{3}$. Siddall and Loeser found a prevalence of $65 \%{ }^{6}$.

However, in a study specifically on neuropathic pain, Werhagen et al. ${ }^{18}$ found a prevalence of $26 \%$ in a group of 402 patients with traumatic lesion in Switzerland, which corroborates our study ${ }^{17}$. They also did not find any correlation between occurrences of pain and patients' ages and level and type of lesion (complete or incomplete). In 
another study, three years later, on patients with nontraumatic spinal cord injuries, the incidence of neuropathic pain in patients with spinal cord injury was $38 \%{ }^{18}$.

Over five years of studying patients with spinal cord injuries, Werhagen et al. found at-level neuropathic pain in $13 \%$ of their patients and below-level pain in $27 \%$, in a total sample of 102 individuals with pain ${ }^{17}$.

Ullrich et al. evaluated 238 individuals with spinal cord injury and did not find any statistically significant correlation between the prevalence of pain and demographic and medical variables, including injury level. However, they noted that tetraplegics tended to feel pain with greater intensity than did paraplegics ${ }^{19}$. Ravenscroft et al. found statistical significance when comparing patients with complete and incomplete lesions and concluded that the patients with complete lesions had more pain than the others $(\mathrm{p}<0.05)^{3}$, in contrast to the findings from our study, from which the data demonstrated that the patients with incomplete lesions had greater prevalence of pain.

Cardenas et al. concluded that pain in general had a prevalence of approximately $80 \%$ and also did not find any differences in pain intensity between the two genders ${ }^{20}$. Also, there was no distinction between age groups. However, these authors stated that the prevalence of pain was higher among individuals who were working when the spinal cord injury occurred, those whose education level was higher and the paraplegic individuals, with incomplete injuries caused by violent acts, thus confirming the data described in the present study, in which individuals with gunshot wounds had a higher prevalence of pain. Despite the high number of patients with gunshot wounds in this local study, these values are not representative of Brazil. Further epidemiological studies are warranted.

The DN4 questionnaire was shown an important instrument for diagnosing neuropathic pain in spinal cord injury patients, especially in those with incomplete lesions in which other types of pains are also prevalent.

For healthcare professionals to be able to provide appropriate pain management following spinal cord injury, investigators need to be aware of this crucial phenomenon.

\section{REFERENCES}

1. Budh CN and Osteraker AL. Life satisfaction in individuals with a spinal cord injury and pain. Clin Rehabil 2007;21:89-96.

2. Burchiel KJ and Hsu FP. Pain and spasticity after spinal cord injury. Spine 2001;26:146-160.

3. Ravenscroft A, Ahmed YS, Burnside IG. Chronic pain after SCI. A patient survey. Spinal Cord 2000;38:611-614.

4. Treede RD, Jensen TS, Campbell JN, et al. Neuropathic pain: redefinition and a grading system for clinical and research purposes. Neurology 2008; 70:1630-1635

5. Eide PK. Pathophysiological mechanisms of central neuropathic pain after spinal cord injury. Spinal Cord 1998;36:601-612.

6. Siddall PJ and Loeser JD. Pain following spinal cord injury. Spinal Cord 2001; 39:63-73.

7. Vall J, Braga $\vee A B$, Almeida PC. Dolor neuropático central y su relación con la calidad de vida de una persona portadora de una lesión medular traumática. Rev Neurol 2006;42:525-529.

8. Vall J, Braga VAB, Almeida PC. Estudo da qualidade de vida em pessoas com lesão medular traumática. Arq Neuropsiquiatr 2006;64:451-455.

9. Wollaars MM, Post MW, Van Asbeck FW, Brand N. Spinal cord injury pain: the influence of psychology factors and impact on quality of life. Clin J Pain 2007;23:383-391.

10. Marino RJ, Barros T, Biering-Sorensen F, et al. ASIA Neurological Standards Committee 2002. International Standards for Neurological Classification of Spinal Cord Injury. J Spinal Cord Med 2003;26(Suppl 1):S50-S56.

11. Bouhassira D, Attal N, Alchaar H, et al. Comparison of pain syndromes associated with nervous or somatic lesions and development of a new neuropathic pain diagnostic questionnaire (DN4). Pain 2005;114:29-36.

12. Bouhassira D. Dolor Neuropático Cuestionario DN4 para La Detección del Dolor Neuropático. RID 2007;2:43-44

13. Ferreira KACL and Teixeira MJ. Tradução e validação da versão brasileira do questionário DN4 para identificação de dor neuropática. Dor é Coisa Séria 2008:4:26-29.

14. Jensen MP and Karoly P. Self-report scales and procedures for assessing pain in adults. In: Turk DC and Melzack R (Eds.). Handbook of Pain Assessment. New York: Guilford Publications; 2001:15-34.

15. Ministério da Saúde (Brasil). Conselho Nacional de Saúde. Resolução n. 196 de 10 de outubro de 1996. Diretrizes e normas regulamentadoras de pesquisa em seres humanos. Mundo Saúde 1996;21:52-61.

16. Finnerup NB, Johannesen IL, Sindrup SH, Bach FW, Jensen TS. Pain and dysesthesia in patients with spinal cord injury: a postal survey. Spinal Cord 2001;39:256-262.

17. Werhagen L, Budh CN, Hultling C, Molander C. Neuropathic pain after traumatic spinal cord injury-relations to gender, spinal level, completeness, and age at the time of injury. Spinal Cord 2004;42:665-673.

18. Werhagen L, Hultling C, Molander C. The prevalence of neuropathic pain after non-traumatic spinal cord lesion. Spinal Cord 2007;45:609-615.

19. Ullrich PM, Jensen MP, Loeser JD, Cardenas DD. Pain intensity, pain interference and characteristics of spinal cord injury. Spinal Cord 2008;46:451-455.

20. Cardenas DD, Bryce TN, Shem K, Richards JS, Elhefni H. Gender and minority differences in the pain experience of people with spinal cord injury. Arch Phys Med Rehabil 2004;85:1774-1781. 